\title{
Protein Globule Formation in the Liver Graft during Cold Preservation for Liver Transplantation: Its Clinical and Pathological Significance*
}

\author{
Changyin Feng ${ }^{1,2}$, Tongmei He ${ }^{1}$, Haijian Huang ${ }^{1}$, Lijuan $\mathrm{Qu}^{1}$, Yi Jiang ${ }^{3}$, Wenhua Zhang ${ }^{3}$, \\ Zhiyong Zheng ${ }^{1 \#}$ \\ ${ }^{1}$ Department of Pathology, Dongfang Hospital, Fujian Medical University, Fuzhou, China; ${ }^{2}$ Department of Pathology, Fujian Medi- \\ cal University Union Hospital, Fuzhou, China; ${ }^{3}$ Department of Hepatobiliary Surgery, Dongfang Hospital, Fujian Medical University, \\ Fuzhou, China. \\ Email: ${ }^{*} 768203566 @ q q . c o m$
}

Received April 21 ${ }^{\text {st }}, 2013$; revised May 21 ${ }^{\text {st }}, 2013$; accepted June $24^{\text {th }}, 2013$

Copyright (C) 2013 Changyin Feng et al. This is an open access article distributed under the Creative Commons Attribution License, which permits unrestricted use, distribution, and reproduction in any medium, provided the original work is properly cited.

\begin{abstract}
In liver transplantation, liver graft ischemia-reperfusion injury occurs mainly due to cold preservation and warm reperfusion. In this research, we study the affection of plasma protein of the donor on liver graft during cold preservation and warm reperfusion. In this study, 34 liver transplantations were performed from 2007 to 2010, and the clinical data were collected retrospectively from the Dongfang Hospital database. 34 specimens were harvested from 34 liver grafts when graft trimming as Group A and 34 specimens harvested from the same 34 liver grafts during liver transplantation surgery but before abdominal closure as B group. All liver tissue specimens were fixed with $40 \mathrm{~g} / \mathrm{L}$ neutral formalin, embedded in paraffin. Light microscopy, transmission electron microscopy, Periodic Acid-Schiff (PAS) stain and immunohistochemical stain of IgG, IgM, IgA, C3d, C4d, Fib, C1q, and CD61 were used. In this study, we found that eosinophilic bodies emerged in liver lobes during liver transplantation which had not been reported previously in the literature. 1) Protein globules were found exclusively in liver graft specimens. The globules were round or oval with sharp edges, measured approximately 1.59 to $9.41 \mu \mathrm{m}$ in diameter, and were scattered in the liver sinusoids or space of Disse or hepatocyte cytoplasm, were stained with IgG, IgM, IgA, Fib, C3d by immunohistochemical staining; 2) There was no statistical significant difference of protein globules number between A group and B group $(\mathrm{P}>0.05)$; 3$)$ IRI score of $\mathrm{B}$ group was not correlated with protein globules number $(\mathrm{P}>0.05)$. Protein globules contain plasma composition, and may form during cold preservation.
\end{abstract}

Keywords: Hepatitis B Virus; Immunohistochemistry; Liver Transplantation; Liver Ischemia-Reperfusion Injury

\section{Introduction}

Liver graft Ischemia-Reperfusion Injury (IRI) occurs during the cold preservation and reperfusion of the liver graft prior to transplantation into the recipient [1-4]. This IRI includes lesions such as fatty degeneration, which may affect the recovery of graft function. As such, it is necessary to evaluate the condition of the liver graft before transplantation. Previous research by our group has shown that eosinophilic bodies emerged in liver lobes during liver transplantation [5]. These eosiniphilic bodies (or "protein globules") had not been reported previously

\footnotetext{
"This study was supported by the Nanjing Military Medicine \& Health Division Fund (No. 08MA103).

${ }^{\#}$ Corresponding author.
}

in the literature. To further investigate these protein globules, light microscopy and transmission electron microscopy were used to observe IRI and protein globules formed in the liver graft. Periodic Acid-Schiff (PAS) stain; immunohistochemical staining of IgG, IgM, IgA, C3d, C4d, Fib, C1q, and CD61 were used to determine the composition of the protein globules.

\section{Material and Methods}

\subsection{Specimen Collection}

A prospectively maintained clinical transplant database that includes recipient and donor demographics, clinical details, and recipient outcomes was used for this study. All of the 95 transplantations performed at Dongfang 
Hospital between January 1, 2007, and June 30, 2010 were reviewed and included in this research. Of the 34 transplant recipients, 29 were male and 5 female, aged from 21 to 76 years (median age 47 years). The liver recipients' pathological diagnoses included 26 cases of hepatocellular carcinoma, 4 cases of cirrhosis with hepatitis B, 1 cases of severe hepatitis B, 1 case Wilson's disease, 1 case of primary biliary cirrhosis, 1 case of autoimmune hepatitis. All the 34 donors were males, aging from 25 to 30 years (median age 27 years), were dead with the cause of brain trauma. All the recipients' and corresponding donors' blood types were matched.

There were 68 liver specimens collected from 34 liver grafts, and these were divided into two groups as experimental groups. The A group included 34 specimens harvested from 34 liver grafts when graft trimming. The B group included 34 specimens harvested from the same 34 liver grafts during liver transplantation surgery but before abdominal closure. 34 liver harvested from the recipients, 30 liver tissue with chronic hepatitis B infection, 17 surgical liver specimens with no liver lesion, 13 autopsy liver specimens with no liver lesion, and 10 liver puncture biopsies about 10 to 20 days after liver transplantation had no cold preservation injury were used in this study as control. Informed consent was obtained from each recipient and donor or their guardians. This research was approved by the ethics committee of Dongfang Hospital.

All the liver grafts were prepared by the rapid multiple donor organ procurement surgical technique, as described elsewhere [6]. Briefly, $3000 \mathrm{ml} \mathrm{HC}$-A(hypertonic citrate purine solution) was used to flush the liver via the aorta, $1500 \mathrm{ml}$ via portal vein and then $2000 \mathrm{ml}$ histidinetryptophan-ketoglutarate (HTK) solution [7]. The liver grafts were stored at $0^{\circ} \mathrm{C}$ to $4^{\circ} \mathrm{C}$ following perfusion with $1000 \mathrm{ml}$ University of Wisconsin solution [7] via the portal vein. All the perfusion pressure was 1.2 meters height. The liver graft warm ischemia time (graft ischemic time in vivo in the donor) was $5 \pm 1.2 \mathrm{~min}$, and the cold ischemia time was $9 \pm 2.5 \mathrm{~h}$. The time of liver transplantation operation was $8.2 \pm 1.25 \mathrm{~h}$. Methylprednisolone, FK506, and/or cyclosporine was used as anti-rejection therapy after operation [8].

\subsection{Reagents}

The rabbit anti-human antibodies to IgG, IgM, IgA, Fib, $\mathrm{C} 3 \mathrm{~d}$ and $\mathrm{C} 1 \mathrm{q}$ were purchased from DAKO (Carpinteria, CA, USA). The rabbit anti-human antibody $\mathrm{C} 4 \mathrm{~d}$ was purchased from Biomedica (Austria), and the rabbit CD61, HBsAg and $\mathrm{HBcAg}$ were purchased from Zhongshan Golden Bridge Company (China). The EliVision TM plus broadspectrum kit (PV-9000) used for immunohistochemical staining was purchased from Maixin Bio company (China), and Trypsin 250 was purchased from Sigma (USA).

\subsection{Specimen Processing and Staining}

All liver tissue specimens of A and B group split into two halves, one half were fixed with $40 \mathrm{~g} / \mathrm{L}$ neutral formalin, embedded in paraffin, cut serially to $3 \mu \mathrm{m}$, stained with hematoxylin and eosin (H\&E), periodic acid-Schiff stain (PAS), Masson's trichrome, and immunohistochemically stained to detect the expression of IgG, IgM, IgA, C3d, C4d, fibrinogen (Fib), Clq, CD61, HBsAg and HBcAg. Another half at the same time were fixed with $3 \%$ glutaraldehyde, osmium tetroxide, embedded in E-618 resin. Ultrathin sections were stained with uranyl acetate and lead citrate and examined under transmission electron microscopy.

Immunohistochemical staining was performed as previously described [9], using tissue sections embedded in paraffin that were then dewaxed. Antigen retrieval except $\mathrm{HBsAg}$ and $\mathrm{HBcAg}$ was performed by pressure cooking the treated tissue sections in citrate buffer $(0.01 \mathrm{~mol} / \mathrm{L}$; $\mathrm{pH}$ 6.0), followed by treatment with $0.1 \%$ trypsin (IgM, IgA, Fib for $16 \mathrm{~min}$; IgG for $11 \mathrm{~min}, \mathrm{C} 3 \mathrm{~d}, \mathrm{C} 4 \mathrm{~d}, \mathrm{C} 1 \mathrm{q}$ for 7 min; CD61 was not treated with trypsin), and then soaked in $3 \% \mathrm{H}_{2} \mathrm{O}_{2}$ for $10 \mathrm{~min}$. The first antibody was then added to the treated tissue sections and incubated at $37^{\circ} \mathrm{C}$ for $2 \mathrm{~h}$, followed by incubation of the tissue sections in a polymer enhancer at $37^{\circ} \mathrm{C}$ for $30 \mathrm{~min}$. Horseradish peroxidase-conjugated anti-C4d antibody for $30 \mathrm{~m}$ at $37^{\circ} \mathrm{C}$, AEC chromogen. The sections were washed with phosphate buffered saline (PBS; $0.01 \mathrm{M}, \mathrm{pH} 7.2$ ) throughout the above steps. We used $10 \%$ non-immune rabbit serum or PBS as negative controls, hepatitis $\mathrm{B}$ tissue as $\mathrm{HBsAg}$ and $\mathrm{HBcAg}$ positive controls, lupus nephritis kidney tissue as IgG, IgM, IgA, C3d, C4d and $\mathrm{C} 1 \mathrm{q}$ positive controls, and arterial thrombus tissue as the CD61 positive control.

\subsection{Lesions Observation Criteria}

The severity of IRI was assessed according to hepatocyte necrosis around the central vein of the hepatic lobule in zone 3 but not in the region under the liver capsule [10, 11] as follows: no necrosis was 0 points, 1 layer of liver cell necrosis around the central vein was 1 point, 2 layers of liver cell necrosis was 2 points, and $\geq 3$ layers of liver cell necrosis was 3 points [11]. Immunohistochemical staining was semiquantitative, and assessed the area occupied by protein globules within the hepatic lobule: no protein globules were 0 points, $<25 \%$ area occupied by protein globules for $1,26 \%$ to $50 \%$ for $2,>51 \%$ for 3 .

\subsection{Image Analysis Measurements of Protein Globules}

In the A group, the IgG stained images were analyzed 
with the Motic Med 6.0 image analysis system. Five fields were randomly selected from each section at 400 magnification. The diameter of every protein globule was measured.

\subsection{Monitoring Graft Function}

In order to eliminate the effect of recipient pre-transplant liver condition and post-transplant rejection, 26 hepatocellular carcinoma cases with no liver failure were selected to monitor the graft function after transplantation ( 1 to 5 days) by assessing the serum alanine aminotransferase (ALT), aspartate aminotransferase (AST) and total bilirubin (TBIL) levels.

\subsection{Statistical Methods}

Non-parametric variables were expressed as median and range, and were compared using the rank sum test. Count variables were compared using the Mann-Whitney test or Kruskal-Wallis $\mathrm{H}$ test. Differences were judged to be statistically significant when $\mathrm{P}<0.05$. Data were analyzed using SPSS version 16.0 software (SPSS 16.0, Inc., Chicago, IL).

\section{Results}

\subsection{Lesions under the Light Microscope}

All the 34 liver grafts included in this study, 20 liver specimens had a normal appearance, 6 had mild chronic hepatitis B, 8 had mild fat degeneration.

All the 34 liver graft hepatocytes in A group were mildly swelling, and hepatocytes around the central vein of hepatic lobule zone 3 displayed mild coagulative necrosis. Varying amounts of protein globules were scattered in the lobule. They were stained uniformly red or purple with H\&E (Figure 1), PAS (Figure 2) or Masson's trichrome (Figure 3), and appeared mostly clear

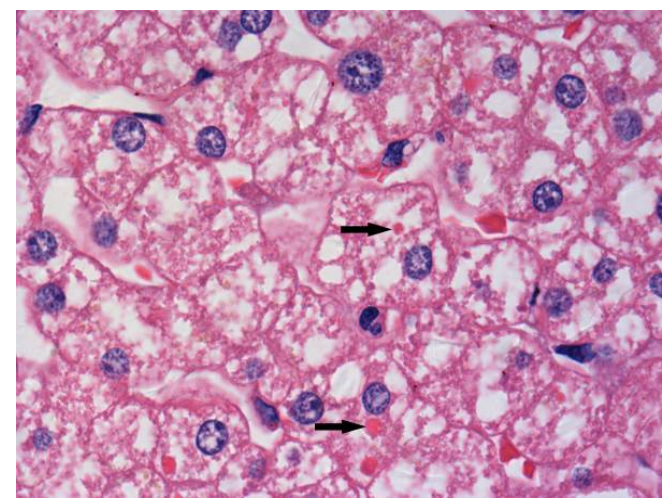

Figure 1. Protein globules (arrows) in liver graft were stained uniformly red with Hematoxylin and Eosin, more deeply stained than hepatocyte cytoplasm, but less deeply stained than RBC. Therefore these were not hepatocyte cytoplasm or fragment of $\mathrm{RBC}(\times 1000$ magnification).

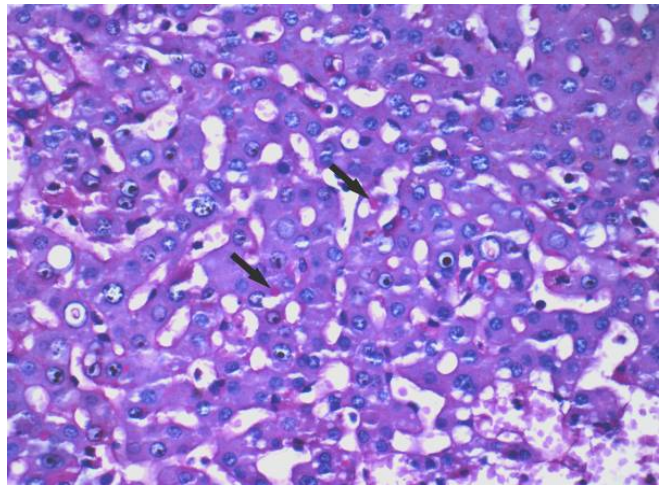

Figure 2. Protein globules (arrows) in hepatocyte cytoplasm were stained uniformly red with periodic acid-Schiff stain (PAS). Therefore these were not fragment of RBC, otherwise they should not be stained with PAS. These globules contain glycogen or polysaccharide that can be stained with PAS ( $\times 400$ magnification).

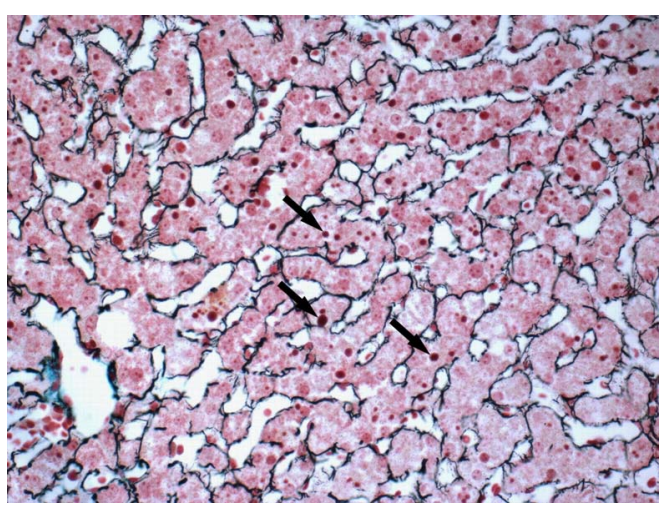

Figure 3. Protein globules (arrows) in hepatocyte cytoplasm were stained uniformly purple with Masson's trichrome. The fibrous scaffold was stained to more clearly observe the protein globules $(\times 400$ magnification $)$.

under Masson's trichrome staining. The protein globules were round or oval with sharp edges, between 1.59 and $9.41 \mu \mathrm{m}$ in diameter, and scattered in the liver sinusoids, the space of Disse or in the hepatocyte cytoplasm. The number of protein globules decreased from Zone 3 to Zone 1 in the lobule.

Hepatocyte necrosis, apoptosis and eosinophilic degeneration were all present in Zone 3. Focal bruising or bleeding with leaking of a few neutrophils and mononuclear cells, hepatic sinusoidal endothelial cell swelling, and necrosis were also observed in Group B specimens. Data presented in Table 1 shows a higher IRI average score in Group B specimens compared to Group A specimens (Table 1, $\mathrm{P}<0.01$ ).

\subsection{Lesions in Liver Graft Specimens Observed Using the Transmission Electron Microscope}

Specimens of Group A had only mild swelling of mito- 
Table 1. Ischemia-reperfusion injury (IRI) of the liver graft in the $A$ and $B$ groups.

\begin{tabular}{cccccc}
\hline \multirow{2}{*}{ Group } & No. & \multicolumn{5}{c}{ IRI score $^{*}$} \\
\cline { 3 - 6 } & & 0 & 1 & 2 & 3 \\
\hline A & 34 & 3 & 24 & 7 & 0 \\
B & 34 & 0 & 9 & 18 & 7 \\
\hline
\end{tabular}

*The A group specimens IRI score compared with B group, $\mathrm{P}<0.05$.

chondria and distribution of dense glycogen was uniform. There were also no membrane-wrapped ball bodies (Figure 4) with sharp edges in the cytoplasm of liver cells, and composition of granular material was uniform when observed with medium electron density.

In contrast to results observed in Group A, mitochondria of specimens in Group B exhibited more swelling, and became rounded or spherical in shape or ruptured in some cases; the presence of mitochondrial vacuoles also increased in Groups B compared to mitochondria observed in specimens in Group A. The number of glycolgen granules decreased resulting in a more sparse distribution in specimens in Groups B compared to those in Group A. The cellular matrix had a lower electron-density and vacuolation increased in Group B specimens compared to those of Group A. The microvillus on the micro-duct surface was swelled and the number of microvillus reduced. The nuclear membranes were disrupted, and nuclear heterochromatin reorganized into blocks and underwent shrinkage. Chromatin condensed into a half-moon or cap shape and attached to the nuclear membrane, apoptotic bodies formed, and endothelial cells contracted while their nucleus became round.

\subsection{Immunohistochemical Staining Results}

Immunohistochemical staining was used to identify protein globules in specimens from liver grafts. Protein globules in Groups A and B specimens had various scores of $\operatorname{IgG}$ (Figure 5), $\operatorname{IgM}, \operatorname{Ig} \mathrm{A}$, Fib and $\mathrm{C} 3 \mathrm{~d}$, as assessed by immunohistochemical staining, while $\mathrm{C} 4 \mathrm{~d}, \mathrm{Clq}$ and CD61 were negative. However, there was no significant difference in $\operatorname{IgG}, \operatorname{IgM}, \operatorname{IgA}$ and $\mathrm{C} 3 \mathrm{~d}$ scores between Groups A and B (Table 2, P > 0.05). IgG had the highest score of all the parameters assessed using immunohistochemical staining, so $\operatorname{IgG}$ score can present the number of protein globules. All the specimens in Group B were divided into two groups according to their IgG score less than 2 or greater than or equal to 2 . There was also no significant difference in the IRI score between the $\operatorname{IgG}<$ 2 group and $\operatorname{IgG} \geq 2$ group (Table 3, $P>0.05$ ). All the grafts were divided into two groups according to the time of cold ischemia: $<9 \mathrm{~h}$ and $\geq 9 \mathrm{~h}$. There was no correlation between the presence of this globules and the length of cold ischemia (Table 4, $\mathrm{P}>0.05$ ).

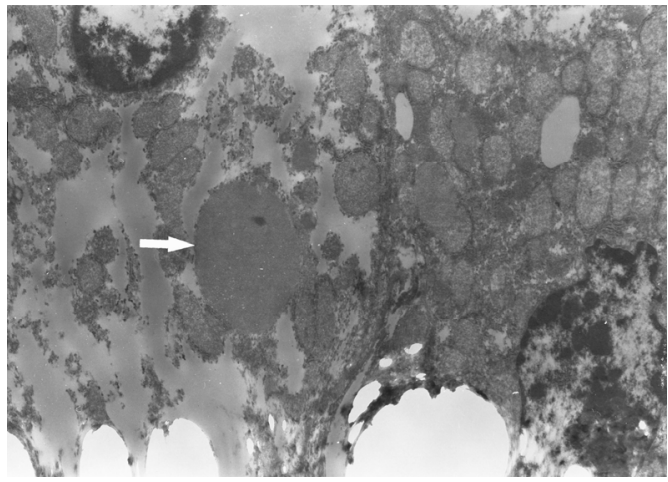

Figure 4. Electronic micrograph of the protein globule (arrow) in hepatocyte cytoplasm with medium electron density ( $\times 6.3 \mathrm{~K}$ magnification).

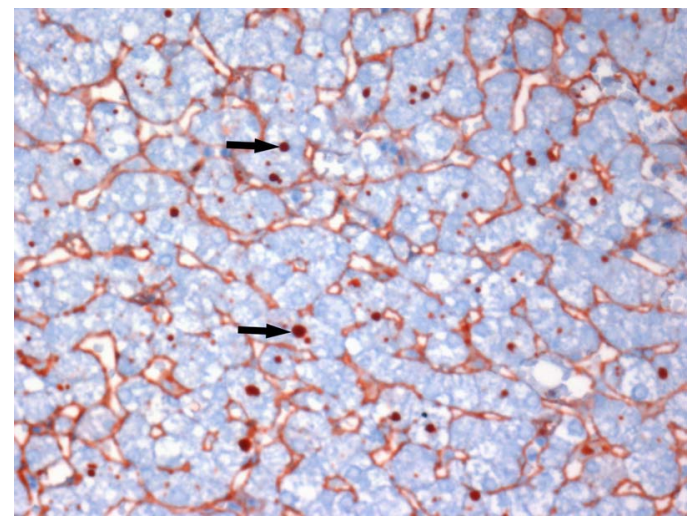

Figure 5. Liver specimens harvested before abdominal closure. Protein globules (arrows) in hepatocyte cytoplasm stained with IgG. Liver sinusoids were also stained for IgG. EliVision, IgG $(\times 400$ magnification $)$.

\subsection{Protein Globules and Liver Graft Function in 5 Days Post-Operation}

In Group A, 26 cases which had hepatocellular carcinoma (HCC) with no liver failure were selected and then divided into two groups according to the $\operatorname{IgG}$ score: Group $\mathrm{L}<2$ and Group $\mathrm{H} \geq 2$. Liver function was assessed by using AST, AST and TBIL. There was no significant difference in ALT, AST and TBIL between L and $\mathrm{H}$ group (Figure 6, $\mathrm{P}>0.05$ ).

\subsection{The Result of the Control Group}

All the 34 recipients' liver, 30 livers with chronic hepatitis $\mathrm{B}, 30$ livers with no liver lesion did not find protein globules that found in liver graft.

\section{Discussion}

\subsection{The Mechanism of Globulin Droplet Formation}

As reported in the literature, there are two forms of liver 
Table 2. Immunohistochemical staining results of protein globules for Groups A and B.

\begin{tabular}{|c|c|c|c|c|c|c|c|c|c|c|c|c|c|c|c|c|c|c|c|c|c|}
\hline \multirow{2}{*}{ Group } & \multirow{2}{*}{ No. } & \multicolumn{4}{|c|}{$\operatorname{IgG}^{\dagger \dagger}$} & \multicolumn{4}{|c|}{$\operatorname{IgA}^{\dagger}$} & \multicolumn{4}{|c|}{$\operatorname{IgM}^{\dagger}$} & \multicolumn{4}{|c|}{$\mathrm{Fib}^{\dagger}$} & \multicolumn{4}{|c|}{$\mathrm{C} 3 \mathrm{~d}^{\dagger}$} \\
\hline & & 0 & 1 & 2 & 3 & 0 & 1 & 2 & 3 & 0 & 1 & 2 & 3 & 0 & 1 & 2 & 3 & 0 & 1 & 2 & 3 \\
\hline A & 34 & 4 & 20 & 7 & 3 & 10 & 18 & 1 & 4 & 9 & 20 & 4 & 1 & 9 & 16 & 8 & 1 & 27 & 5 & 2 & 0 \\
\hline B & 34 & 6 & 16 & 10 & 2 & 12 & 16 & 5 & 1 & 9 & 17 & 8 & 0 & 6 & 21 & 6 & 1 & 21 & 10 & 3 & 0 \\
\hline
\end{tabular}

${ }^{\dagger}$ There was no significant difference in IgG, IgM, IgA and C3d scores between the two groups, P $>0.05$; ${ }^{\star} \operatorname{IgG}$ score present the number of protein globules.

Table 3. IgG and IRI of B group.

\begin{tabular}{cccccc}
\hline \multirow{2}{*}{ Group } & No. & \multicolumn{4}{c}{$\mathrm{IRI}^{\S}$ score } \\
\cline { 3 - 6 } & & 0 & 1 & 2 & 3 \\
\hline $\mathrm{L}(\mathrm{IgG}$ score $<2)$ & 22 & 0 & 5 & 12 & 5 \\
$\mathrm{H}(\mathrm{IgG}$ score $\geq 2)$ & 12 & 0 & 4 & 6 & 2 \\
\hline${ }^{\S}$ L group compared with H group, IRI scores were not different $\mathrm{P}>0.05$.
\end{tabular}

Table 4. IgG score of cases with different cold ischemia time.

\begin{tabular}{cccccc}
\hline $\begin{array}{c}\text { Time of cold } \\
\text { ischemia }\end{array}$ & No. & 0 & 1 & 2 & 3 \\
\hline$<9 \mathrm{~h}$ & 16 & 3 & 7 & 6 & 1 \\
$\geq 9 \mathrm{~h}$ & 18 & 3 & 9 & 4 & 1 \\
\hline
\end{tabular}

"cold ischemia time $<9 \mathrm{~h}$ group compared with group of cold ischemia time $\geq 9 \mathrm{~h}$, IgG scores were not different $\mathrm{P}>0.05$.

cell necrosis in IRI of liver graft $[3,12,13]$. One form is scattered or clustered eosinophilic protein particles or apoptotic bodies, and the other is liver cell necrosis around the central vein. Both the two forms are thought to belong to the ischemic liver injury for many years [13]. In this research, we found that eosinophilic protein particles (protein globules) were stained uniformly red with PAS, which is specific staining of glycogen or polysaccharide [14]. Therefore protein globules were not fragment of RBC [15] or apoptotic bodies of liver cell, for both of which did not contain glycogen or polysaccharide [16]. The protein globules were medium electron density with no membrane-wrapping. Immunohistochemical staining showed that the protein globules contained in their plasma $\operatorname{IgG}, \operatorname{IgM}, \operatorname{IgA}$, Fib and $\mathrm{C} 3 \mathrm{~d}$, rather than $\mathrm{C} 4 \mathrm{~d}$, C1q complement activation fragments [17-24], and CD61positive platelet components $[25,26]$, as had been previously reported in IRI and related liver cell necrosis. IgG, $\operatorname{IgM}$, IgA, Fib and C3d in the protein globules may be the main components of plasma protein aggregation rather than products of a humoral immune reaction, or the microthrombi. This suggests that protein globules are not related to liver cell necrosis.

So how did protein globules form?

Table 2 shows that protein globules are present in liver graft when graft trimming and before abdomen was closed, and the number of protein globules of the two
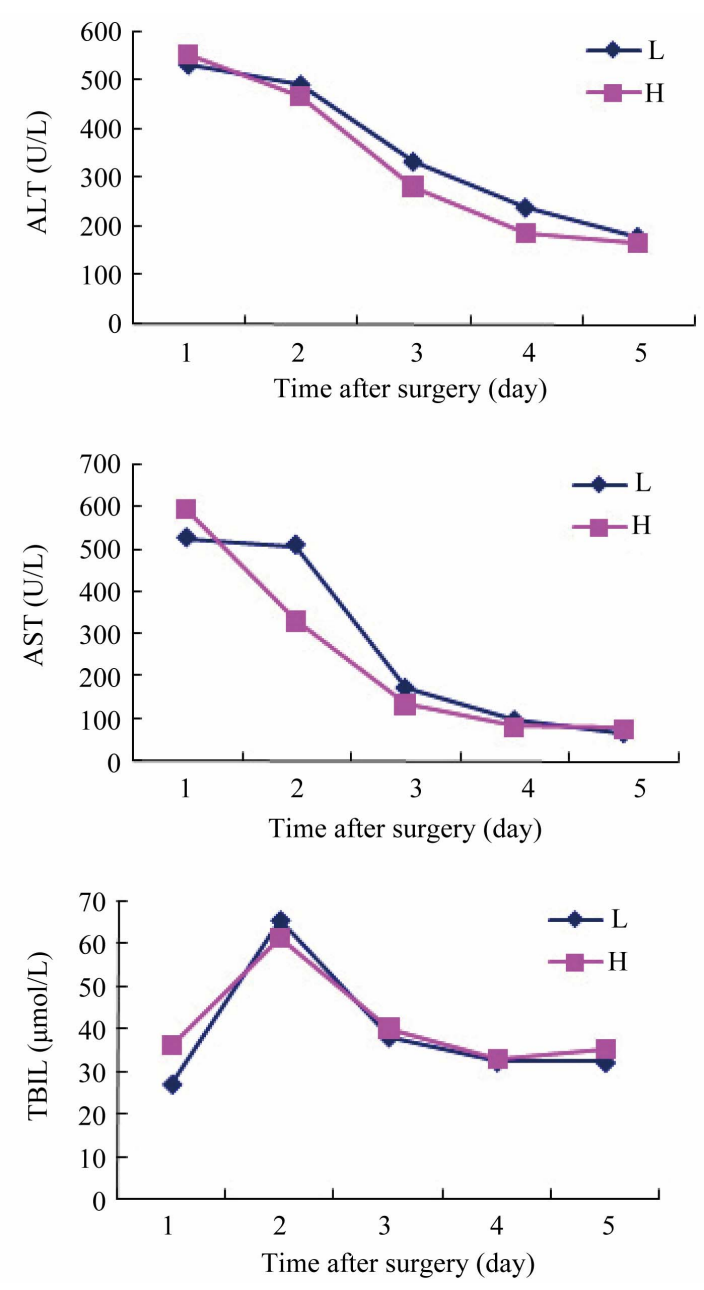

Figure 6. Liver graft function was assessed 5 days after transplantation in patients who had HCC with no liver failure. There was no significant difference in serum ALT, AST and TBIL between grafts in group $L($ IgG score $<2)$ and grafts in group $\mathrm{H}(\mathrm{IgG}$ score $\geq 2)(\mathrm{P}>0.05)$.

groups are approximately same. This indicating that protein globules have formed before the graft implanted. The factors involved in the protein globules formation is nothing more than the following factors: warm ischemic injury of the liver graft, cold preservation injury of the liver graft during transport $[1,22,27]$ and the donor already exists certain diseases such as hepatitis B. In this study, the recipient's liver and the autopsy liver in the control group which all present a certain degree of warm 
ischemic injury, but they had no protein globules. So warm ischemic injury is not the protein globules formed factor. Protein globules did not present in liver specimens with hepatitis B, so hepatitis B virus is not the protein globules formed factor. In this study, the donor did not have disease that eosinophilic bodies can be formed in the liver, even have, the eosinophilic bodies in the liver are different form protein globules(for details see 3.3). The difference between the liver grafts, the livers of the recipients 'and the control group is that the former had cold perfusion and cold preservation while the later two did not have. Therefore, the donor liver cold perfusion and cold preservation may be the factors for the formation of protein globules. The data in Table 4 shows that the number of protein globules is not correlated with cold preservation time, and this may be due the forming process of protein globules in the liver graft is relatively short. Under transmission electron microscope, the outer periphery of protein globules were not wrapped in a membranous structure, while the other hepatic phagocytic formed bodies are wrapped in membranous structure, so protein globules were not the liver phagocytosis.

We speculate the formation process of protein globules is as follows: when low temperature perfusion fluid into the graft, the preexisting donor serum globulin may agglutinate into protein globules [28-30] and then may be stranded in the hepatic sinusoids. Under the perfusion pressure, protein globules easily entered into the liver cells with relatively weak membrane caused by cold temperature.

Liver is divided into three functional zones according to the oxygen supply [31]. Zone 1 encircles the portal tracts where the oxygenated blood from hepatic arteries enters into the liver. Zone 3 located around the central veins where oxygenation is poor and was more susceptible to cold ischemic injury. Therefore the number of protein globules decreased from Zone 3 to Zone 1 .

\subsection{Clinical and Pathological Significance of Protein Globules}

The number of protein globules had no correlation with IRI score (Table 4), which indicates that the formation of protein globules due to cold preservation, and the cell necrosis observed around the central vein belong to two different forms of tissue damage. There was no significant difference of ALT, AST and TBIL between L and H group. These results suggested that protein globules have little effect on the changes of liver function indicators in 5 days post-operation (Figure 5). The protein globules formed under low temperature may dissolved quickly after liver graft re-warming, and were then digested by enzymes in liver cytoplasm. This maybe attributed to that the protein globules were not found in the liver graft 10 to 20 days post-transplantation in this research, which is consistent with the previous report [32].

\subsection{The Identification of Protein Globules and Other Similar Bodies in Liver Tissue}

Protein globules should be differentiated from other similar bodies in liver tissue, including huge mitochondria, Mallory bodies, eosinophilic bodies, pale bodies, anti-trypsin bodies, and Lafora bodies. The significant difference between protein globules and the six bodies above is that protein globules contain immunoglobulin IgG, IgM, IgA, Fib and C3d, whereas the latter six do not. Huge mitochondria are round eosinophilic bodies with hematoxylin and eosin in liver cytoplasm, and are mitochondrial structures identified by electron microscopic examination [33]. Mallory bodies are irregular eosinophilic clumps with hematoxylin and eosin in liver cytoplasm, and are protein aggregates where the intermediate filament combines with ubiquitin. Mallory bodies commonly appear in alcoholic liver disease or other nonalcohol-induced liver injury [34,35]. Eosinophilic bodies are round or oval in shape. Strong eosinophilic bodies are formed after liver cell apoptosis, and commonly appear in viral hepatitis [36]. Pale bodies are round or amorphous in shape with pale cytoplasmic inclusions that contain hematoxylin and eosin, and retain fibrinogen in the endoplasmic reticulum, commonly appear in hepatocellular carcinoma [37]. Anti-trypsin bodies are aggregates of alpha-1-antitrypsin that are present in liver cytoplasm. Anti-trypsin bodies are red, glass-like bodies when stained with PAS, and commonly appear in patients with alpha-1-antitrypsin deficiency [38]. Lafora bodies contain round or granular pale inclusions, and have a narrow zonal pellucida. Lafora bodies commonly appear in patients with myoclonus-epilepsy [39].

\section{Acknowledgements}

Thanks are due to Ling Zeng and Min Li for assistance with immunohistochemical staining and to Qinghong Liu for assistance with ultrathin sections and to Dehua Zeng for assistance with data process.

\section{REFERENCES}

[1] S. J. Zhang, C. J. Zhu, Y. F. Zhao, J. Li and W. Z. Guo, "Different Ischemic Preconditioning for Rat Liver Graft: Protection and Mechanism," Hepatobiliary \& Pancreatic Diseases International, Vol. 2, No. 4, 2003, pp. 509-512.

[2] S. Yan, L. M. Jin, Y. X. Liu, L. Zhou, H. Y. Xie and S. S. Zheng, "Outcomes and Mechanisms of Ischemic Preconditioning in Liver Transplantation," Hepatobiliary \& Pancreatic Diseases International, Vol. 9, No. 4, 2010, pp. 346-354. 
[3] H. Shimizu, M. Miyazaki, H. Ito, K. Nakagawa, S. Ambiru, A. Kato, et al., "Mechanism of Cold IschemiaReperfusion Induced Graft Injury after Orthotopic Liver Transplantation in Rats," Hepatogastroenterology, Vol. 48, No. 37, 2001, pp. 216-219.

[4] J. W. Kupiec-Weglinski and R. W. Busuttil, "Ischemia and Reperfusion Injury in Liver Transplantation," Transplantation Proceedings, Vol. 37, No. 4, 2005, pp. 16531656. doi:10.1016/j.transproceed.2005.03.134

[5] C. Y. Feng, "Research on Humoral and Cellular Immune Markes of Liverg Graft before and after Reperfusion," Master's Thesis, Fujian Medical University, Fuzhou, 2009.

http://epub.cnki.net/grid2008/brief/detailj.aspx?filename= 2009150523.nh\&dbname=CMFD2009

[6] T. E. Starzl, C. Miller, B. Broznick and L. Makowka, "An Improved Technique for Multiple Organ Harvesting," Surgery, Gynecology \& Obstetrics, Vol. 165, No. 4, 1987, pp. 343-348.

[7] X. N. Feng, X. Xu and S. S. Zheng, "Current Status and Perspective of Liver Preservation Solutions," Hepatobiliary \& Pancreatic Diseases International, Vol. 5, No. 4, 2006, pp. 490-494.

[8] Y. Calmus, "Immunosuppression after Liver Transplantation," La Presse Médicale, Vol. 38, No. 9, 2009, pp. 1307-1313. doi:10.1016/j.lpm.2009.06.004

[9] Y. H. Yu and Z. Y. Zheng, "Color Atlas of Renal Biopsy Pathology," Fujian Science and Technology Press, Fuzhou, 2008.

[10] W.-M. Cong, "The Guide for Pathological Diagnosis and Classification of Common Disease after Liver Transplantation (I)," Chinese Journal of Organ Transplantation, 2008, pp. 49-51.

[11] W.-M. Cong, "The Guide for Pathological Diagnosis and Classification of Common Disease after Liver Transplantation (II)," Chinese Journal of Organ Transplantation, 2009, pp. 690-691.

[12] N. S. Goldstein, J. Hart and K. J. Lewin, "Diffuse HeapTocyte Ballooning in Liver Biopsies from Orthotopic Liver Transplant Patients," Histopathology, Vol. 18, No. 4, 1991, pp. 331-338. doi:10.1111/j.1365-2559.1991.tb00854.x

[13] L. Luo, Y. Chen and X.-L. Ji, "Clinicopathological Observation and Analysis of Donor Liver and Biopsy in Liver Transplantation," Chinese Journal of Hepatobiliary Surgery, Vol. 15, No. 12, 2009, pp. 885-887.

[14] J. F. McManus, "Histological and Histochemical Uses of Periodic Acid," Stain Technology, Vol. 23, No. 3, 1948, pp. 99-108.

[15] J. A. Chasis and S. B. Shohet, "Red Cell Biochemical Anatomy and Membrane Properties," Annual Review of Physiology, Vol. 49, 1987, pp. 237-248. doi:10.1146/annurev.ph.49.030187.001321

[16] T. Ihara, T. Yamamoto, M. Sugamata, et al., "The Process of Ultrastructural Changes from Nuclei to Apoptotic Body," Virchows Archiv, Vol. 433, No. 5, 1998, pp. 443447. doi:10.1007/s004280050272

[17] S. H. Kim and H. J. Jeong, "Glomerular C4d Deposition
Indicates in Situ Classic Complement Pathway Activation, but Is Not a Marker for Lupus Nephritis Activity," Yonsei Medical Journal, Vol. 44, No. 1, 2003, pp. 75-80.

[18] X. Bu, Z. Zheng, Y. Yu, L. Zeng and Y. Jiang, "Significance of C4d Deposition in the Diagnosis of Rejection after Liver Transplantation," Transplantation Proceedings, Vol. 38, No. 5, 2006; pp. 1418-1421. doi:10.1016/j.transproceed.2006.03.018

[19] X. Bu, Z. Zheng, C. Wang and Y. Yu, "Significance of C4d Deposition in the Follicular Lymphoma and MALT Lymphoma and Their Relationship with Follicular Dendritic Cells," Pathology_Research and Practice, Vol. 203, No. 3, 2007, pp. 163-167. doi:10.1016/j.prp.2006.11.004

[20] X. Ding, Z.-Y. Zheng, C. Wang, L. Zeng and Y. Jiang, "ABO-Incompatible Liver Transplantation: A Pathological Analysis of 2 Cases," World Chinese Journal of Digestology, 2008, pp. 2056-2060.

[21] K. Murata and W. M. Baldwin 3rd, "Mechanisms of Complement Activation, C4d Deposition, and Their Contribution to the Pathogenesis of Antibody-Mediated Rejection," Transplantation Reviews (Orlando), Vol. 23, No. 3, 2009, pp. 139-150. doi:10.1016/j.trre.2009.02.005

[22] P. S. Hair, J. Q. Gronemus, K. B. Crawford, V. P. Salvi, K. M. Cunnion, N. M. Thielens, et al., "Human Astrovirus Coat Protein Binds C1q and MBL and Inhibits the Classical and Lectin Pathways of Complement Activation," Molecular Immunology, Vol. 47, No. 4, 2010, pp. 792-798. doi:10.1016/j.molimm.2009.10.006

[23] L. A. Tan, B. Yu, F. C. Sim, U. Kishore and R. B. Sim, "Complement Activation by Phospholipids: The Interplay of Factor H and C1q," Protein Cell, Vol. 1, No. 11, 2010, pp. 1033-1049.

[24] L. T. Roumenina, M. Radanova, B. P. Atanasov, K. T. Popov, S. V. Kaveri, S. Lacroix-Desmazes, et al., "Heme Interacts with c1q and Inhibits the Classical Complement Pathway," The Journal of Biological Chemistry, Vol. 286, No. 18, 2011, pp. 16459-16469. doi:10.1074/jbc.M110.206136

[25] A. Mateo, C. O. Pintado, J. P. de la Lastra, R. Dusinsky, M. Simon, J. Naessens, et al., "Ruminant Cluster CD41/ CD61," Veterinary Immunology and Immunopathology, Vol. 52, No. 4, 1996, pp. 251-253. doi:10.1016/0165-2427(96)05570-5

[26] A. Merono, C. Lucena, A. López, J. J. Garrido, L. L. de Pérez and D. Llanes, "Immunohistochemical Analysis of Beta3 Integrin (CD61): Expression in Pig Tissues and Human Tumors," Histology and Histopathology, Vol. 17, No. 2, 2002, pp. 347-352.

[27] C. Fondevila, R. W. Busuttil and J. W. Kupiec-Weglinski, "Hepatic Ischemia/Reperfusion Injury-A Fresh Look," Experimental and Molecular Pathology, Vol. 72, No. 4, 2003, pp. 86-93. doi:10.1016/S0014-4800(03)00008-X

[28] T. Okazaki, A. Nakahashi, T. Uchiyama, A. Imoto, K. Morikawa, T. Okano, et al., "Composition of Cryoglobulin and Cryoprecipitate," Clinical Chemistry and Laboratory Medicine, Vol. 47, No. 9, 2009, pp. 1161-1163.

[29] J. S. Davidson, “Appropriate Cryoglobulin Investiga- 
tions," Annals of Clinical Biochemistry, Vol. 47, No. 5, 2010, p. 491. doi:10.1258/acb.2010.010088

[30] G. Motyckova and M. Murali, "Laboratory Testing for Cryoglobulins," American Journal of Hematology, Vol. 86, No. 6, 2011, pp. 500-502. doi:10.1002/ajh.22023

[31] Chapter 2, "Anatomy and Physiology of the Liver. Arjan van der Plaats. The Groningen Hypothermic Liver Perfusion System for Improved Preservation in Organ Transplantation," 2005.

http://dissertations.ub.rug.nl/FILES/faculties/medicine/20 05/a.van.der.plaats/c2.pdf

[32] H. F. Eggink, N. Hofstee, C. H. Gips, R. A. Krom and H. J. Houthoff, "Histopathology of Serial Graft Biopsies from Liver Transplant Recipients," American Journal of Pathology, Vol. 114, No. 1, 1984, pp. 18-31.

[33] T. Inagaki, S. Kobayashi, N. Ozeki, M. Suzuki, Y. Fukuzawa, K. Shimizu, et al., "Ultrastructural Identification of Light Microscopic Giant Mitochondria in Alcoholic Liver Disease," Hepatology, Vol. 15, No. 1, 1992, pp. 46-53. doi:10.1002/hep. 1840150110

[34] P. Fickert, M. Trauner, A. Fuchsbichler, C. Stumptner, K. Zatloukal and H. Denk, "Mallory Body Formation in Primary Biliary Cirrhosis Is Associated with Increased Amounts and Abnormal Phosphorylation and Ubiquitination of Cytokeratins," Journal of Hepatology, Vol. 38, No. 4, 2003, pp. 387-394. doi:10.1016/S0168-8278(02)00439-7
[35] H. Denk, C. Stumptner, A. Fuchsbichler and K. Zatloukal, "Alcoholic and Non-Alcoholic Steatohepatitis," Verhandlungen der Deutschen Gesellschaft für Pathologie, 2005, pp. 137-143.

[36] Z. Schaff and P. Nagy, "Novel Factors Playing a Role in the Pathomechanism of Diffuse Liver Diseases: Apoptosis and Hepatic Stem Cells," Orvosi Hetilap, Vol. 145, No. 35, 2004, pp. 1787-1793.

[37] W. S. Moon, H. C. Yu, M. J. Chung, M. J. Kang and D. G. Lee, "Pale Bodies in Hepatocellular Carcinoma," Journal of Korean Medical Science, Vol. 15, No. 5, 2000, pp. 516-520.

[38] J. A. Burrows, L. K. Willis and D. H. Perlmutter, "Chemical Chaperones Mediate Increased Secretion of Mutant Alpha 1-Antitrypsin (alpha 1-AT) Z: A Potential Pharmacological Strategy for Prevention of Liver Injury and Emphysema in Alpha 1-AT Deficiency," Proceedings of the National Academy of Sciences of the United States of America, Vol. 97, No. 4, 2000, pp. 1796-1801. doi:10.1073/pnas.97.4.1796

[39] P. Gómez-Garre, E. Gutiérrez-Delicado, C. Gómez-Abad, J. Morales-Corraliza, V. E. Villanueva and S. R. de Córdoba, "Hepatic Disease as the First Manifestation of Progressive Myoclonus Epilepsy of Lafora," Neurology, Vol. 68, No. 17, 2007, pp. 1369-1373. doi:10.1212/01.wnl.0000260061.37559.67 